Info Artikel:

Diterima: $17 / 11 / 2017$

Direvisi: 25/12/2017

Dipublikasikan: 26/01/2018

Dipublikasikan oleh :

Indonesian Institute for Counseling, Education and Therapy (IICET)

Akses Online :

http://jurnal.iicet.org

\title{
Peningkatan Aktivitas dan Hasil Belajar Siswa Kelas V dalam Pembelajaran PKn dengan Model Arias di SD Negeri 18 Batang Anai
}

\author{
Nurbayenti
}

\begin{abstract}
Abstrak
Penelitian ini dilatar belakangi oleh kurangnya keaktifan siswa dalam belajar. Hal ini menyebabkan hasil belajar siswa pada pembelajaran PKN cenderung menurun. Tujuan penelitian ini adalah Peningkatan aktivitas dan hasil belajar PKn siswa kelas V menggunakan model ARIAS di SD Negeri 18 Batang Anai. Jenis penelitian adalah penelitian tindakan kelas yang dilakukan dalam dua siklus. Setiap siklus dua kali pertemuan. Subjek dari penelitian ini adalah siswa kelas VA SDN 18 Batang Anai, yang berjumlah 26 orang. Hasil penelitian menunjukkan bahwa Persentase aktivitas belajar siswa melakukan diskusi pada sikus sebesar I 71,42\% meningkat menjadi sebesar 90,47 \% pada siklus II, Persentase aktivitas belajar siswa menjawab pertanyaan pada sikus sebesar I sebesar $47,61 \%$ meningkat menjadi sebesar $80,95 \%$ pada siklus II, Persentase aktivitas belajar siswa menulis laporan hasil diskusi pada sikus sebesar I sebesar 40,47\% meningkat menjadi sebesar 95,23\% pada siklus II, Hasil belajar siswa pada siklus I yang tuntas belajar sebesar $52,38 \%$ meningkat pada siklus II sebesar $90,47 \%$. Aktivitas guru dalam melaksanakan pembelajaran model ini mengalami peningkatan dari siklus I ke siklus II. Sehingga adanya keselarasan antara aktvitas siswa dan guru. Kesimpulan dari penelitian ini adalah model pembelajaran AIRAS dapat meningkatkan aktivitas dan hasil belajar PKn siswa kelas VSDN 18 Batang Anai.
\end{abstract}

Kata kunci: Model ARIAS, Aktivitas Siswa, Hasil Belajar, PKn

Copyright (C) 2018 IICET - All Rights Reserved

Indonesian Institute for Counseling, Education and Theraphy (IICET)

\section{PENDAHULUAN}

Pendidikan Kewarganegaraan (PKn) adalah pendidikan yang memberikan pendidikan dasar tentang pemerintahan, tata cara demokrasi, tentang kepedulian, sikap, dan pengetahuan politik. Melalui PKn melahirkan warga negara memiliki pengetahuan politik yang mampu mengambil keputusan politik secara rasional. Jika ini terwujud, maka warga masyarakat akan demokratis dan berpartisipatif untuk menciptakan negara yang aman dan sejahtera. Hal ini bisa terjadi melalui pendidikan yang berorientasi pada pengembangan berpikir kritis dan bertindak demokratis.

PKn adalah usaha sadar dan terencana dalam proses pembelajaran agar peserta didik secara aktif dalam mengembangkan potensi dirinya untuk memiliki kecerdasan, kecakapan, keterampilan serta kesadaran tentang hak dan kewajiban sebagai warganegara, penghargaan terhadap hak-hak asasi manusia, kemajemukan bangsa, perlestarian lingkungan hidup, kesetaraan gender, demokrasi, tanggung jawab sosial, ketaatan pada hukum, serta ikut berperan dalam percaturan global (Pebriyenni. 2009). Pembelajaran PKn di Sekolah Dasar (SD) dimaksudkan sebagai suatu 
proses belajar mengajar dalam rangka membantu peserta didik agar dapat belajar dengan baik dan membentuk manusia Indonesia seutuhnya dalam pembentukan karakter bangsa yang diharapkan mengarah pada penciptaan suatu masyarakat yang menempatkan demokrasi dalam kehidupan berbangsa dan bernegara yang berlandaskan pada Pancasila, UUD, dan norma-norma yang berlaku di masyarakat yang diselenggarakan selam enam tahun.

Hasil observasi yang dilakukan pada proses pembelajaran PKn, guru mengidentifikasi masalah yang dialami siswa yaitu memiliki minat yang kurang dalam kegiatan pembelajaran. Data awal pembelajaran pada kelas V SD 18 Batang Anai ditemui beberapa gejala, di antaranya minat siswa dalam mengajukan pertanyaan teridentifikasi sekitar $25,92 \%$ bertanya dan $74,07 \%$ yang tidak mengajukan pertanyaan. Hal ini menunjukkan bahwa siswa lebih banyak yang tidak mau mengajukan pertanyaan. Minat siswa dalam berdiskusi kelompok teridentifikasi ada 29,62\% yang melaksanakan dan 70,38\% yang tidak melakukan diskusi. Hal ini menunjukkan bahwa lebih banyak siswa yang tidak mau berdiskusi. Kemampuan siswa dalam memahami pelajaran yakni pada ranah kognitif ada 25,92\% siswa yang kemampuannya di atas KKM dan kemampuan siswa dalam merespon pembelajaran yakni pada afektif $22,22 \%$, dengan kata lain belum baik dan belum mencapai KKM. Selain itu hasil belajar siswa juga rendah, hal ini terlihat pada nilai mid semester ada 29,62\% yang tuntas, sedangkan yang tidak tuntas ada 70,37\%, dengan Kriteria Ketuntasan Minimum (KKM) semester 1 yang sudah ditetapkan sekolah untuk mata pelajaran PKn adalah 68. Asumsi sementara bahwa minat siswa dalam belajar tidak tinggi. Minat merupakan dorongan dalam diri seseorang atau faktor yang menimbulkan ketertarikan atau perhatian secara efektif yang menyebabkan dipilihnya suatu objek atau kegitan yang menguntungkan, menyenangkan dan lamakelamaan akan mendatangkan kepuasan dalam dirinya .

Model pembelajaran ARIAS merupakan modifikasi dari model ARCS (Attention, Relevance, Condifidence, Satisfation) sebagai jawaban pertanyaan bagaimana merancang pembelajaran yang dapat mempengaruhi motivasi siswa berprestasi dan hasil belajar siswa. Model pembelajaran ini menarik karena dikembangkan atas dasar-dasar teori belajar dan pengalaman nyata para instruktur. Model ini mengandung 5 komponen yaitu: assurance (percaya diri), relevance (relevansi), interest (minat), assessment (evaluasi), satisfaction (kepuasan/bangga). Modifikasi assurance dan attention menjadi interest. Penggantian nama condifidence (percaya diri) menjadi assurance, karena kata assurance sinonim dengan kata self-confidende (Moris dalam Amri, 2011:70).

Berdasarkan pemaparan di atas, maka dilakukan penelitian dengan judul "Peningkatan Minat dan Hasil Belajar Siswa Kelas V dalam Pembelajaran PKn dengan Model Assurance, Relevance, Interest, Assesment, Satisfaction (ARIAS) di SD Negeri 18 Batang Anai. Rumusan masalah dalam penelitian ini adalah bagaimanakah pembelajaran PKn dengan menggunakan model ARIAS di kelas V SDN Batang Anai?

\section{METODE}

Jenis penelitian yang digunakan dalam penelitian ini adalah penelitian tindakan kelas (classroom action research). Penelitian tindakan kelas Menurut Arikunto, dkk (2010:3) adalah penelitian yang dilakukan oleh guru di dalam kelasnya sendiri melalui refleksi diri, dengan tujuan untuk memperbaiki kinerjanya sebagai guru, sehingga hasil belajar siswa menjadi meningkat. Penelitian ini dilakukan di SD Negeri 18 Batang Anai. Subjek dalam penelitian ini adalah siswa kelas VA berjumlah 27 orang yang terdiri dari 9 orang siswa laki-laki dan 18 orang siswa perempuan. Penelitian tindakan kelas dilakukan dalam dua siklus. Setiap siklus dilakukan dua kali pertemuan. Langkah pembelajaran yang dilaksanakan dalam penelitian adalah:

1. Guru membuka pelajaran dengan berdoa.

2. Menyampaikan tujuan pembelajaran.

3. Menjelaskan materi pelajaran tentang menunjukkan sikap terhadap globalisasi di lingkungannya.

4. Memberi kesempatan kepada siswa untuk berpartisipasi dengan berdiskusi untuk memilih topik yang akan dibicarakan, mengajukan pertanyaan dan demonstrasi. 
5. Mengadakan evaluasi.

6. Memberi penghargaan kepada siswa.

\section{HASIL PENELITIAN DAN PEMBAHASAN}

\section{Hasil Penelitian \\ 1. Perencanaan}

Materi pokok pada siklus I adalah tentang "kebutuhan hidup keluarga dan kebutuhan hidup bertetangga". Kompetensi dasarnya adalah Memahami perlunya saling memenuhi kebutuhan hidup dan menyajikan dinamika saling memenuhi kebutuhan hidup antar daerah untuk menumbuhkan keutuhan nasional. Langkah-langkah pembelajaran yang direncanakan dilaksanakan dalam tiga tahap pembelajaran. Tahap I Pendahuluan, yang dilakukan adalah mengkondisikan kelas, berdo'a, absensi, guru melakukan apersepsi, guru memotivasi siswa untuk semangat belajar, dan menyampaikan tujuan pembelajaran.

Tahap II Kegiatan inti, Eksplorasi yaitu guru mengemukakan manfaat pembelajaran bagi kehidupan siswa, guru memperlihatkan beberapa contoh media gambar, siswa memperhatikan media gambar yang ditampilkan, guru memberi kesempatan kepada siswa untuk bertanya, guru menjelaskan materi pembelajaran, dan guru memberi kesempatan kepada siswa untuk bertanya. Elaborasi, kegiatan yang dilakukan adalah guru bersama siswa membentuk kelompok diskusi, siswa mendiskusikan topik yang akan dibahas pada masing-masing kelompok, siswa melakukan diskusi, guru memfasilitasi siswa dalam berdiskusi, mengadakan komunikasi nonverbal dalam kegiatan pembelajaran seperti demonstrasi dan simulasi, siswa diberi kesempatan untuk bertanya mengenai diskusi kelompok yang telah dilaksanaka, mengadakan komunikasi nonverbal dalam kegiatan pembelajaran seperti demonstrasi dan simulasi, Siswa diberi kesempatan untuk bertanya mengenai diskusi kelompok yang telah dilaksanakan. Kegiatan konfirmasi yang dilakukan adalah guru melakukan penilaian pada setiap kelompok yang menampilkan hasil diskusinya di depan kelas, kelompok yang dapat mengerjakan dengan baik dan tepat waktu akan mendapatkan reward, guru melakukan penilaian untuk mengetahui ketercapaian sisw, guru memberi kesempatan kepada siswa untuk mengadakan evaluasi kepada diri sendiri dan teman sebangkunya, guru memberi kesempatan kepada siswa untuk mengadakan evaluasi kepada teman sebangkunya.

Kegiatan Akhir yang dilakukan adalah siswa bersama guru membuat kesimpulan, memberi penghargaan kepada siswa yang aktif dalam bertanya, siswa bersama guru melakukan refleksi kegiatan belajar hari ini, dan siswa memimpin doa di akhir pembelajaran.

\section{Pelaksanaan}

Pelaksanaan pembelajaran dilaksanakan dengan dua kali pertemuan. Pertemuan pertama dan kedua dilaksanakan sesuai dengan rencana yang telah dibuat. Setelah pembelajaran pada pertemuan kedua, maka dilaksanakanlah tes. Pelaksanaan tes ini untuk melihat pemahaman siswa terhadap materi yang dipelajari. Soal tes terdiri dari 10 soal objektif dan 5bsoal esai. Guru menyampaikan beberapa hal yang perlu diperhatikan pada saat tes berlangsung yaitu semua siswa dilarang melihat buku catatan, mencontoh jawaban teman, berdiskusi dengan teman sebangku, dan melihat buku paket.

\section{Pengamatan}

Hasil analisis observer terhadap aktivitas guru menunjukkan bahwa pembelajaran yang dilaksanakan kurang berlangsung dengan baik. Begitu juga halnya dengan pengamatan terhadap aktivitas siswa dalam pembelajaran yang belum optimal. Untuk lebih jelasnya, hasil observasi terhadap aktivitas siswa dapat diuraikan sebagai berikut:

\section{Aktivitas Siswa}

Jurnal Penelitian Pendidikan Indonesia | Akses Online : http://jurnal.iicet.org 
Hasil analisis aktivitas belajar siswa terhadap pembelajaran PKn dapat dilihat pada Tabel1 berikut.

Tabel 1

Aktivitas Siswa pada Siklus I

\begin{tabular}{ccccccc} 
Indikator & \multicolumn{5}{c}{ Pertemuan Ke } & Rata-rata \\
\cline { 2 - 5 } & Jumlah & 1 & $\%$ & Jumlah & $\%$ & persentase \\
A & 14 & & 66,66 & 16 & 76,19 & 71,42 \\
B & 10 & & 47,61 & 12 & 57,14 & 52,37 \\
C & 5 & & 23,80 & 8 & 38,09 & 40,47 \\
Rata-rata & 9,6 & & 46,02 & 12 & 57,14 & 53,16 \\
Jumlah Siswa & & 21 & & & 21 & \\
\hline
\end{tabular}

Keterangan:

Indikator A: Siswa melakukan diskusi.

Indikator B: Siswa menjawab pertanyaan.

Indikator C: Siswa menanggapi jawaban pertanyaan.

Berdasarkan data yang tertera pada tabel di atas dapat dikemukakan bahwa rata-rata siswa melakukan diskusi adalah 71,42 \%, berarti sebagian besar. Hal ini menunjukkan bahwa sebagian besar siswa sudah melaksanakan diskusi. Siswa menjawab pertanyaan adalah 52,37\%. Persentase ini menunjukkan bahwa setengah dari siswa sudah mulai bisa menjawab pertanyaan dari guru dan temannya. Namun masih ada siswa yang malu-malu menjawab pertanyaan guru dan teman lainnya. Persentase siswa menanggapi jawaban pertanyaan adalah $40,47 \%$, berarti sebagian besar siswa masih banyak yang belum bisa menanggapi pertanyaan yang diberikan guru. Hal ini dikarenakan siswa masih takut dan malu.

\section{Aktivitas Guru}

Aktivitas guru dalam pembelajaran pada siklus I dapat di presentasekan dalam mengelola pembelajaran. Aktivitas guru dapat dilihat pada tabel berikut:

Tabel 2

Aktivitas Guru menggunakan Model Assurance, Relevance, Interest, Assesment, Satisfaction (ARIAS)

\begin{tabular}{cccc} 
Pertemuan & Jumlah Skor & Persentase \\
\hline I & 9 & $60,00 \%$ \\
II & 10 & $66,67 \%$ \\
Rata-rata & & 9,50 & $63,33 \%$ \\
& Target & & $70 \%$ \\
\hline
\end{tabular}


Dari tabel di atas dapat dibuat analisis bahwa persentase guru dalam mengelola pembelajaran memiliki rata-rata persentase $60 \%$ sehingga belum dapat dikatakan baik. Hal ini disebabkan karena guru belum terbiasa menyajikan pembelajaran dengan menggunakan Model Assurance, Relevance, Interest, Assesment, Satisfaction (ARIAS)

\section{Hasil Belajar Siklus I}

Hasil tes siklus I dapat dilihat pada tabel berikut ini. Pada tabel terlihat ketuntasan siswa dalam belajar.

Tabel 3

\section{Ketuntasan dan Rata-rata Hasil Tes pada Siklus I}

\begin{tabular}{lcc}
\multicolumn{1}{c}{ Uraian } & Nilai & Target \\
\hline Jumlah siswa yang mengikuti tes & 21 & - \\
Jumlah siswa yang tuntas tes & 11 & - \\
Jumlah siswa yang tidak tuntas tes & 10 & - \\
Persentase ketuntasan tes & $52,38 \%$ & $70 \%$ \\
Rata-rata nilai tes & & 70 \\
\hline
\end{tabular}

Mencermati tabel di atas, terlihat bahwa siswa yang tuntas sudah lebih dari $50 \%$ siswa. Siswa yang belum tuntas kurang dari 50\%. Hal ini menunjukkan bahwa kegiatan pembelajaran yang dilaksanakan belum berhasil membawa siswa tuntas dalam belajar. Target ketuntasan belajar yang ditetapkan dalam penelitian ini secara klasikal yaitu $70 \%$ dari jumlah siswa. Sedangkan ketercapaian ketuntasan belajar pada siklus I ini belum sesuai target.

\section{Refleksi}

Kegiatan refleksi dilakukan berdasarkan hasil observasi pada siklus I. Ini terlihat pada indikator aktivitas siswa yaitu siswa bertanya, menjawab dan menanggapi masih kurang dan belum mencapai target yang telah ditentukan yaitu $70 \%$. Identifikasi masalah yang terjadi pada pembelajaran siklus I dari aspek guru, yaitu: 1) Guru masih terfokus penyampaian materi pembelajaran. 2) Guru masih kurang terampil dalam mengendalikan kelas sehingga siswa kurang aktif dalam pembelajaran. 3) Guru kurang memotivasi siswa sehingga mereka kurang bertanya dan menanggapi. Aspek siswa, masalah yang terjadi pada pembelajaran siklus I, yaitu: 1) Siswa belum terbiasa bertanya atau masih malu-malu untuk bertanya dan menanggapi. 2) Siswa belum terbiasa dengan metode pembelajaran Model Assurance, Relevance, Interest, Assesment, Satisfaction, sehingga siswa masih ragu-ragu dan takut untuk bertanya, berdiskusi ataupun menanggapi.

Hasil belajar siswa pada siklus I, dapat disimpulkan bahwa belum mencapai target yang ditetapkan. Persentase tersebut dapat dilihat dari siswa yang tuntas belajar masih di bawah $70 \%$ yaitu hanya $61,90 \%$. Siswa yang tuntas dalam pembelajaran hanya 11 orang dari 21 orang siswa yang mengikuti tes. Solusi dari permasalahan di atas adalah: 1) Guru harus lebih banyak menggunakan media dalam pembelajaran. 2) Guru harus lebih terampil dalam mengendalikan kelas terutama dalam belajar kelompok. 3) Guru harus lebih memotivasi siswa dengan cara memberikan penguatan atau pujian agar mereka bersemangat dalam belajar.

\section{Siklus II}

\section{Perencanaan}

Perencanaan pada siklus II dilaksanakan dengan berpedoman pada hasil refleksi siklus I. Perencanaan perbaikan terhadap tindakan yang akan diterapkan pada siklus II, yaitu, 1) Guru harus lebih banyak menggunakan media pembelajaran seperti gambar. 2) Guru harus lebih 
terampil dalam mengendalikan kelas terutama dalam belajar kelompok. 3) Guru lebih banyak memotivasi siswa dan memberikan penguatan atau pujian. Langkah-langkah pembelajaran yang direncanakan untuk mencapai indikator keberhasilan siswa sebagai berikut:

Tabel 4

Langkah Pembelajaran Model ARIAS

\begin{tabular}{|c|c|c|}
\hline Kegiatan Awal & Kegiatan Inti & Kegiatan Akhir \\
\hline $\begin{array}{l}\text { - Membangkitkan } \\
\text { skemata siswa dengan } \\
\text { tanya jawab dengan } \\
\text { siswa } \\
\text { - Menyebutkan tujuan } \\
\text { pembelajaran }\end{array}$ & $\begin{array}{l}\text { - } \begin{array}{l}\text { Membagi kelas menjadi } 10 \\
\text { kelompok }\end{array} \\
\text { - Guru membagikan kartu soal } \\
\text { pada tiap kelompok } \\
\text { - Guru meminta siswa membuat } \\
\text { jawaban } \\
\text { - Setiap kelompok } \\
\text { mengemukakan hasil diskusi } \\
\text { untuk berbagi jawaban dengan } \\
\text { seluruh siswa di kelas }\end{array}$ & $\begin{array}{l}\text { - Menyimpulkan pelajaran } \\
\text { - Tanya jawab secara klasikal } \\
\text { sebagai umpan balik secara } \\
\text { klasikal } \\
\text { - Evaluasi }\end{array}$ \\
\hline
\end{tabular}

\section{Pelaksanaan}

Guru memulai pelajaran dengan meminta siswa untuk berdo'a. Setelah berdoa, guru mengkondisikan siswa untuk siap belajar. Kemudian guru melakukan apersepsi tentang materi sebelumnya dan menyampaikan tujuan pembelajaran. Selanjutnya, guru meminta siswa untuk duduk pada kelompoknya masing-masing. Guru menjelaskan kembali aturan diskusi dengan model pembelajaran Assurance, Relevance, Interest, Assesment, Satisfaction (ARIAS). Kemudian guru membagikan kartu soal yang berbentuk sepotong kertas kepada setiap anggota kelompok. Kartu soal ini digunakan untuk menulis pertanyaan dan jawabannya tengtang materi yang dipelajari.

Pada kegiatan inti (tergambar eksplorasi), guru melakukan tanya jawab tentang materi "macam-macam keputusan bersama". Kemudian, guru menyebutkan dan menuliskan tujuan dibentuknya KPK di papan tulis. Setelah menulis, guru memantau siswa sambil berjalan dan memberikan nasehat kepada siswa yang tidak memperhatikan pelajaran yang sedang berlangsung. Kemudian guru menempel gambar orang berdiskusi, dan melakukan tanya jawab tentang gambar tersebut. Setelah itu, guru memberikan aba-aba kepada setiap anggota kelompok untuk menuliskan jawaban dari pertanyaan yang ada pada kartu. Masingmasing siswa tampak serius menuliskan jawaban. Setelah itu guru memberikan umpan balik positif.

Pada kegiatan penutup, guru bersama siswa menyimpulkan materi yang telah dipelajari. Guru meminta siswa membuat kesimpulan di dalam buku catatan masing-masing. Tes dilaksanakan pada akhir sikus II selesai. Soal tes sebanyak 15 butir, yang terdiri dari 10 soal objektif dan 5 soal essay.

\section{Pengamatan}

Pengamatan dilakukan terhadap aktvitas siswa dan guru. Aktivitas siswa dapat dilihat pada tabel berikut ini. 


\begin{abstract}
Aktivitas Siswa
Aktivitas belajar siswa dalam pembelajaran PKn menggunakan model ARIAS dapat dilihat pada Tabel berikut ini.
\end{abstract}

\title{
Tabel 5
}

Aktivitas Siswa pada Siklus II

\begin{tabular}{cccccc} 
Indikator & \multicolumn{5}{c}{ Pertemuan Ke } \\
\cline { 2 - 6 } & Jumlah & 1 & $\%$ & Jumlah & $\%$ \\
A & 17 & 80,95 & 19 & 90,47 \\
B & 15 & 71,42 & 15 & 71,42 \\
C & 15 & 71,42 & 20 & 95,23 \\
Rata-rata & 16,3 & & 74,59 & 18 & 83,59 \\
Jumlah Siswa & & 21 & & & 21 \\
\hline
\end{tabular}

Keterangan:

Indikator A: Siswa melakukan diskusi

Indikator B: Siswa menjawab pertanyaan

Indikator C: Siswa menanggapi jawaban pertanyaan

Berdasarkan tabel 5 di atas dapat diketahui bahwa: Aktivitas siswa melakukan diskusi pada siklus II sudah meningkat sebesar 90,47\% dengan kategori baik. Aktivitas siswa dalam menjawab pertanyaan pada siklus II meningkat sebesar $71,42 \%$ dengan kategori baik. Aktivitas siswa menanggapi jawaban pertanyaan pada siklus II sudah meningkat sebesar 95,23\% dengan kategori baik. Hasil analisis aktivitas siswa pada siklus II ini terlihat bahwa semua aktivitas pembelajaran sudah dilaksanakan secara baik.

\section{Aktivitas Guru}

Aktivitas yang dilakukan guru dalam pembelajaran pada siklus II sebagai berikut.

\section{Tabel 6.}

\section{Aktivitas Guru pada Siklus II}

\begin{tabular}{ccc} 
Pertemuan & Jumlah Skor & Persentase \\
\hline I & 11 & $73,33 \%$ \\
II & 13 & $86,66 \%$ \\
Rata-rata & 12 & $79,99 \%$ \\
Target & & $70 \%$ \\
\hline
\end{tabular}

Tabel 6 menunjukkan bahwa aktivitas guru dalam pembelajaran sudah melebihi target yaitu sebesar 79,99\%. Hal ini dapat disimpulkan bahwa aktivitas guru dalam pembelajaran sudah baik. 


\section{Hasil Belajar Siswa}

Hasil belajar PKn siswa pada siklus II dapat dilihat pada Tabel 7 berikut:

Tabel 7.

\section{Hasil Belajar Siswa pada Siklus II}

\begin{tabular}{llc} 
No. & \multicolumn{1}{c}{ Uraian } & Jumlah \\
\hline 1. & Siswa yang mengikuti tes & 21 \\
2. & Siswa yang tuntas belajar & 19 \\
3. & Siswa yang tidak tuntas belajar & 2 \\
$\mathbf{4 .}$ & Persentase ketuntasan belajar siswa & $90,47 \%$ \\
$\mathbf{5 .}$ & Rata-rata skor tes & \\
\hline
\end{tabular}

Mencermati tabel di atas, terlihat bahwa persentase ketuntasan hasil belajar siswa sudah mencapai 90, 47\%. Hanya ada 2 orang siswa yang tidak tuntas. Ini menunjukkan bahwa model pembelajaran ARIAS sudah dapat meingkatkan hasil belajar PKn siswa di kelas V SD. Siswa yang sebanyak 2 orang ini perlu dilakukan program perbaikan.

\section{Refleksi}

Berdasarkan pengamatan observer terhadap aktivitas siswa dari siklus I ke siklus II, rata-rata persentase peningkatannya sudah mencapai 25\%. Namun, pada indikator kedua (yaitu siswa menjawab pertanyaan) cenderung siswa yang sama dengan siswa yang menanggapi pada siklus I. Artinya, motivasi siswa secara keseluruhan untuk mengemukakan pendapat masih kurang. Untuk itu perlu ditingkatkan motivasi siswa dalam pembelajaran. Hasil pengamatan menunjukkan bahwa kegiatan guru dalam mengelola pembelajaran sudah mengalami peningkatan dibandingkan siklus sebelumnya. Pada siklus II sudah berada pada kategori baik.

Pada tabel 8 berikut dapat dijelaskan persentase peningkatan aktivitas siswa, aktivitas guru dan ketuntasan belajar.

\section{Tabel 8}

\section{Peningkatan Aktivitas Siswa, Aktivitas Guru dan Ketuntasan Belajar}

\begin{tabular}{llccr}
\multirow{2}{*}{$\mathbf{N}$} & Aspek & \multicolumn{2}{c}{ Rata-rata Persentase } & \multirow{2}{*}{ Peningkatan } \\
\cline { 3 - 4 } $\mathbf{1}$ & Aktivitas Siswa & $53,16 \%$ & $88,88 \%$ & $36 \%$ \\
$\mathbf{2}$ & Aktivitus I & Siklus II & $17 \%$ \\
$\mathbf{3}$ & Ketuntasan Belajar & $63,33 \%$ & $79,99 \%$ & $38 \%$
\end{tabular}

Tabel 8 menunjukkan bahwa aktivitas siswa dari siklus I ke siklus II meningkat sebesar 36\%. Aktivitas guru juga meningkat sebesar $17 \%$ dibandingkan dengan siklus I. Ketuntasan belajar siswa juga meningkat $38 \%$ dibandingkan dengan siklus I.

\section{PEMBAHASAN}

Pembelajaran dengan menggunakan Model Assurance, Relevance, Interest, Assesment, Satisfaction (ARIAS) merupakan hal baru bagi siswa. Saat pelaksanaan pembelajaran, guru banyak menemui berbagai masalah terutama dalam pengelolaan kelas. Pada model ini yang diamati kegiatan yang dilaksanakan dalam pembelajaran adalah siswa dan guru. Keberhasilan 
pelaksanaan model pembelajaran ARIAS ini ditentukan oleh keaktifan siswa dan guru. Guru dan siswa saling melengkapi dalam pelaksanaan pembelajaran.

\section{Aktivitas Siswa}

Hal yang paling mendasar dituntut dalam proses pembelajaran adalah aktivitas siswa. Aktivitas siswa dalam proses pembelajaran merupakan interaksi antara guru dan siswa ataupun siswa dengan siswa. Jika ini terjadi, diharapkan suasana belajar menjadi segar dan kondusif. Hal ini dapat dilihat dari presentase peningkatan aktivitas siswa pada Tabel 9 sebagai berikut.

Tabel 9

\section{Peningkatan Aktivitas Siswa pada Siklus I dan Siklus II}

No. Indikator Aktivitas Siswa

1. Siswa melakukan diskusi

2. Siswa menjawab pertanyaan

3. Siswa menanggapi jawaban pertanyaan

Rata-rata kedua siklus

\begin{tabular}{|c|c|c|}
\hline \multicolumn{2}{|c|}{ Rata-rata Persentase } & $\%$ \\
\hline Siklus I & Siklus II & Peningkatan \\
\hline $71,42 \%$ & $90,47 \%$ & $19,05 \%$ \\
\hline $47,61 \%$ & $80,95 \%$ & $33,34 \%$ \\
\hline $40,47 \%$ & $95,23 \%$ & $54,76 \%$ \\
\hline $53,16 \%$ & $88,88 \%$ & $35,72 \%$ \\
\hline
\end{tabular}

Berdasarkan tabel di atas dapat disimpulkan bahwa pembelajaran PKn menggunakan Model Assurance, Relevance, Interest, Assesment, Satisfaction (ARIAS) yang dilaksanakan dapat meningkatkan aktivitas siswa. Hal ini terbukti dari kenaikan rata-rata presentase untuk masingmasing indikator keberhasilan aktivitas yang telah ditetapkan.

Pada siklus II guru banyak memberikan kesempatan kepada siswa untuk melakukan tanya jawab ketika masing-masing anggota kelompok mempresentasikan hasil kerja kelompoknya ke depan kelas. Anggota kelompok lain memberikan tanggapan terhadap kelompok yang mempresentaskan hasil kerja kelompok tersebut. Siswa yang aktif dalam belajar telah menunjukkan adanya rasa percaya diri. Hal ini berarti komponen pertama dari model ini sudah terpenuhi yaitu assurance (percaya diri) yang berhubungan dengan sikap percaya, yakin akan berhasil atau yang berhubungan dengan harapan untuk berhasil (Keller dalam Amri, 2011:71). Terhadap siswa yang telah paham dengan materi maka guru memberikan umpan balik kepada siswa dengan bertanya dan memberikan penguatan kepada siswa lain.

\section{Aktivitas Guru}

Keberhasilan siswa dalam pembelajaran pada umumnya dilihat juga dari pengelolaan pelaksanaan pembelajaran pada persentase aktivitas guru. Dalam hal ini terlihat peningkatan aktivitas guru dari siklus I ke siklus II. Persentase aktivitas guru dapat dilihat pada Tabel 10 di bawah ini:

Tabel 10

Aktivitas Guru pada Siklus I dan Siklus II

\begin{tabular}{rcc} 
No & Siklus & Rata-rata per Siklus \\
\hline 1. & I & $63,33 \%$ \\
2. & II & $79,99 \%$ \\
3. & Rata-rata Persentase & $71,66 \%$ \\
\hline
\end{tabular}

Jurnal Penelitian Pendidikan Indonesia | Akses Online : http://jurnal.iicet.org 
Dari tabel di atas dapat disimpulkan bahwa pelaksanaan pembelajran menggunakan Model Assurance, Relevance, Interest, Assesment, Satisfaction (ARIAS) pada siklus I menghasilkan ratarata persentase $63,33 \%$, sehingga baru dapat dikategorikan cukup. Pada siklus II dapat dilihat ratarata persentase $79,99 \%$, sehingga dapat dikatakan baik, hal ini disebabkan guru sudah mulai terbiasa menggunakan Model Assurance, Relevance, Interest, Assesment, Satisfaction (ARIAS) sehingga pelaksanaan pembelajara lebih meningkat dibandingkan siklus I.

\section{Hasil Belajar}

Keberhasilan siswa dalam pembelajaran pada umumnya dilihat dari nilai-nilai tinggi. Selain itu partisipasi siswa juga memegang peranan dalam menciptakan nilai-nilai yang tinggi tersebut. Pada siklus I, rata-rata persentase ketuntasan belajar siswa mencapai 52,38\% dengan rata-rata nilai 70. Sedangkan pada siklus II, persentase ketuntasan belajar siswa mencapai $90,47 \%$ dengan ratarata nilai 79,58. Dengan beraktivitas, siswa sudah menjadi subjek belajar, yaitu mengalami pengalaman belajarnya sendiri berperan aktif dalam proses pembelajaran. Dengan meningkatnya aktivitas siswa dalam pembelajaran PKn, diharapkan hasil belajar atau nilai PKn siswa juga meningkat.

\section{KESIMPULAN DAN SARAN}

\section{Kesimpulan}

Berdasarkan hasil penelitian dapat disimpulkan bahwa model pembelajaran ARIAS dapat meningkatkan aktivitas siswa, aktivitas guru dan hasil belajar siswa kelas $\mathrm{V}$ dalam pembelajaran PKn di SDN 18 Batang Anai.

\section{Saran}

Sehubungan dengan hasil penelitian yang diperoleh, maka saran yang dapat diberikan sebagai berikut:

1. Bagi guru, pelaksanaan pembelajaran menggunakan model ARIAS dapat menjadi salah satu alternatif pelaksanaan pembelajaran PKn.

2. Bagi guru/peneliti lainnya dapat melaksanakan model ini pada materi PKn lainnya atau mata pelajaran yang lain.

\section{DAFTAR PUSTAKA}

Amri, Sofan, dkk. 2011. Strategi Pembelajaran Sekolah Terpadu. Jakarta: Prestasi Pustaka Publisher.

Arikunto, Suharsimi, dkk. 2010. Penelitian Tindrirm Kelas. Jakarta: Rineka Cipta.

Djamil, Krisna Wati. 2012. Peningkatan 59 ;i dan Hasil Belajar IPA Melalui Model Pembelajaran ARIAS Pada Siswa Kelas IV SDN 01 Batang Anai Kabupaten Padang Pariaman. Skripsi. Padang. Universitas Bung Hatta.

Labschool Jakarta (http://wijayalabs.wordpress.com/2008/04/22/model-model-pembelajaran/) diakses pada 08 Mei 2013

Pebriyenni. 2009. Pembelajaran IPS II (Kelas Tinggi). Padang: Prodi PGSD FKIP Universitas Bung Hatta Kerjasama dengan Direktorat Jendral Pendidikan Tinggi Departemen Pendidikan Nasional.

Sudjana, Nana. 2012. Penilaian Hasil Proses Belajar Mengajar. Bandung: Remaja Rosdakarya.

Susanto, Ahmad. 2013. Teori Belajar dan Pembelajaran di Sekolah Dasar. Jakarta: Karisma Putra Utama. 
Umroh, Siti Mahmudah. 2013. Efektifitas Model ARIAS (Assurance, Relevance, Interest, Assesment, dan Satisfaction) untuk Meningkatkan Hasil Belajar dan Motivasi Berprestasi Peserta Didik Kelas X MA Miftahussalam Demak Tahun Ajaran 2012/2013 pada Materi Pokok Stoikiometri. Thesis. IAIN Wali Songo.

Yusrizal. 2010. Bahan Ajar Pembelajaran PKn SD Kelas Tinggi. Padang: Bung Hatta University Press. 